\title{
Robot Boat Design For Real-Time Monitoring Of River Water Quality
}

\author{
Santra Prabowohendhi ${ }^{*, a, 1}$, Ferida Yuamita ${ }^{\text {b,2, }}$, Andung Jati Nugroho ${ }^{c, 3}$ \\ a,b,c University of Technology Yogyakarta \\ ${ }^{1}$ santraprabowohendhi@gmail.com ${ }^{*},{ }^{2}$ feridayuamita@staff.uty.ac.id, ${ }^{3}$ andung.nugroho@staff.uty.ac.id
}

\begin{abstract}
As the population grows in big cities and watersheds, it will significantly impact river waters. One of the settlements located on the banks of the river Winongo is Ngampil village, Ngampil sub-district, Yogyakarta City. According to data from the Yogyakarta City Central Statistics Agency, the population of the Ngampil sub-district increased in 2018 to 18,591 inhabitants, from 2016 with 10,540 inhabitants, the Winongo River is used by the Ngampil residents for fish farming by making cages and also residents who use the Winongo River for activities environmental conservation. One effort to control water pollution is to monitor water quality consistently. The problem in this research is the absence of tools to monitor river water quality. Therefore, it is necessary to design an efficient monitoring tool to read water quality with a ph indicator in real-time using the hovercraft method through the internet of things method. Utilizing this robot boat tool can monitor river water quality using an automatic drive system and display the river water's $\mathrm{pH}$ indicator on the website. This research showed river water quality at 6:00 in the morning with a pH value of water 6.81 information Poor / Contaminated by Weight, daytime at 12.00 with a $\mathrm{pH}$ value of water 6.77 information Poor / Contaminated by Weight, and afternoon at 18.00 with a water ph value of 6.66 information Poor / Severely polluted.
\end{abstract}

Keywords: Monitoring, Robot Boat, Real-Time

\section{INTRODUCTION}

As the population increases in big cities and watersheds, it will impact quite an extensive river pollution. The source of pollutants produced comes from domestic and industrial waste in the river basin. The river, which initially served as a component of the hydrological cycle, has now changed its function as a waste disposal site. The ecosystem around the river, which is supposed to be the place for the organism's life cycle, has now become embankments and inspection roads [1]. According to [2], the city of Yogyakarta generally passes three rivers, namely the Winongo, Code, and Gajahwong rivers. The Winongo River is a tributary of the Opak River with a length of $43.75 \mathrm{~km}$, which flows in Sleman Regency, Yogyakarta City, and Bantul Regency. In urban areas along the Winongo River, the dominant land uses are settlements, offices, public facilities, and industry. The Winongo River receives waste from household activities as well as from industrial activities in the vicinity. It harms river water quality [3].

A study conducted by [4] the quality of Winongo river water with $\mathrm{pH}$ (Power of Hydrogen) parameters showed a value of 7.5. One of the settlements on the Winongo river banks is Ngampilan sub-district, Ngampilan district, Yogyakarta City. According to data from the Yogyakarta City Central Bureau of Statistics, the Ngampilan sub-district population increased in 2018 became 18,591 people, from 2016 to 10,540 people. Based on the Central Statistics Agency
(BPS), Ngampilan Village, with an area of $0.45 \mathrm{~m} 2$ and the population from year to year has increased. With this density, in 2018 Ngampilan sub-district was the highest density, amounting to 23,129 people. The high population density can be seen in residential areas located on dense riverbank areas and violating river boundaries, one of which is the Ngampilan block RW 02 [5].

Ngampilan people use the Winongo River for fish farming by making cages, and residents who use the Winongo River for environmental conservation activities, namely by preserving plants (vegetation) along the river cliffs.

One of the efforts to control water pollution is by monitoring water quality consistently. Water quality monitoring needs to be held at every point of the river to determine the feasibility of river water that has been contaminated by industrial waste, households, hospitals/health centers, and laboratories. Monitoring data can be obtained by monitoring manually or continuously. According to the minister of environment and forestry regulation about wastewater quality monitoring, article 2 number 1: "The person in charge of a business and/or activity in monitoring the quality of wastewater and reporting on the implementation of monitoring the quality of wastewater is obliged to install and operate the sparring."

\section{RESEARCH METHODS}

This research focused on designing a Robot Boat for Monitoring River Water Quality in real-time, designing Robot Boat-shaped hovercraft. The lifter 
system's design is to design an integrated hovercraft to face land and water contours, hoping that if it passes through rocky terrain, the Robot Boat will not get stuck. The Robot Boat uses a conductivity sensor to determine the water quality level in the river with a parameter, namely the water's $\mathrm{pH}$, by displaying on the website page in real-time. This research was conducted to design a Robot Boat to monitor and measure river water quality with water $\mathrm{pH}$ parameters in real-time. This Robot Boat is designed to use an automatic system according to a predetermined point via a laptop using additional software in the form of ardupilot, a manual system using a remote, and the Internet of Things system to transmit water quality data from the Robot Boat to the website in real-time.

\section{RESULTS AND DISCUSSION}

1. Testing Tools

Robot Boat testing is carried out by setting the connection with components then connecting the Robot Boat with the software in the form of a Website and Ardupilot, successfully then the Robot Boat will sound, and the red light installed on the front of the Robot Boat will light up. Mission planners can give orders to run through a laptop with a remote automatic mode and manual mode.

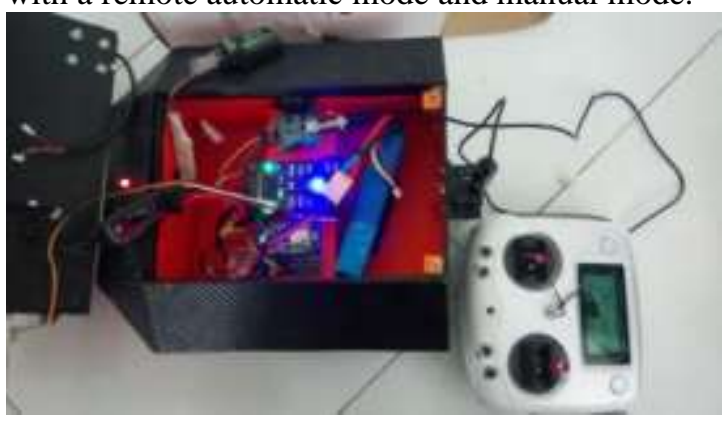

Figure 1. Testing of Robot Boat Components

\section{Work Tools System}

The Robot Boat tool's working system determines how to use the Robot Boat to monitor river water quality. The following Figure 2 shows the working system for the use of the Robot Boat Tool.

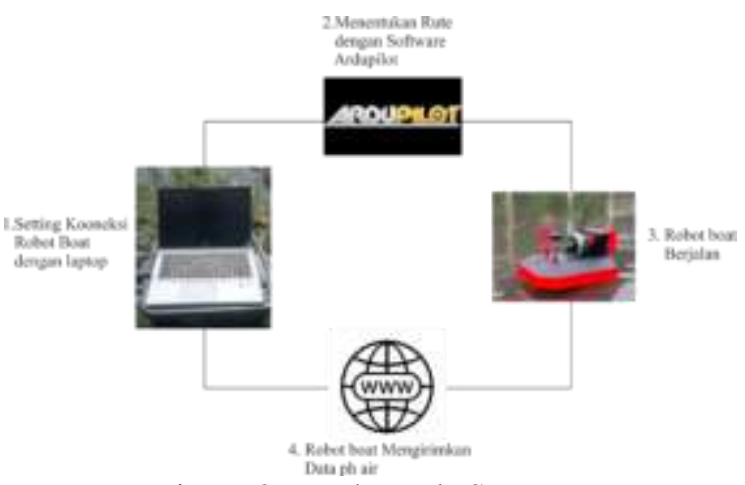

Figure 2. Work Tools System

The explanation of the flowchart steps for how to use the Robot Boat, namely:

i) set up the Robot Boat component connection with the laptop using the Mission Planner.

ii) Determine the route of the Robot Boat using Mission Planner.

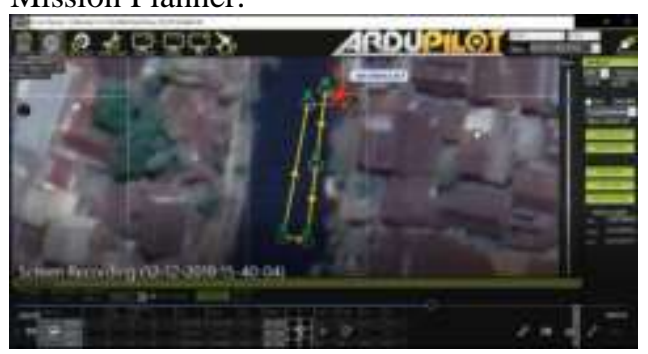

Figure 3. Determining a route with Mission Planner

iii)Robot Boat runs on the river according to a predetermined route.

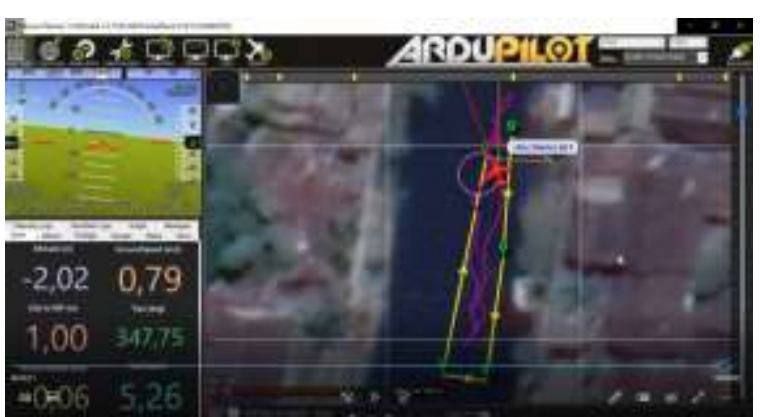

Figure 4. Robot Boat Route with Mission Planner

iv) Robot Boat will send data in the form of water $\mathrm{pH}$ value to the Website.

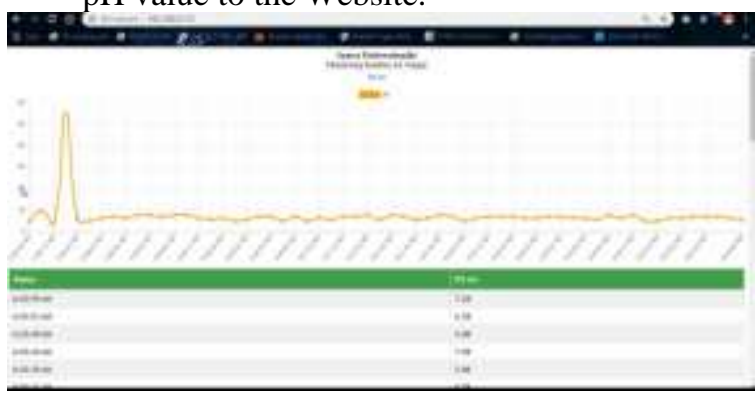

Figure 5. Data $\mathrm{pH}$ value of water on the Website

\section{Test Results}

The Robot Boat, which has been designed in the previous stage, is implemented using ESP8266 as a microcontroller, the Vernier PH-BTA pH sensor functions as a water $\mathrm{pH}$ detector, ardupilot as an automatic system with additional GPS and telemetry components, a battery as power for the Robot Boat and an EDF motor as a mover.

In the ESP8266 section, a program testing phase is carried out to connect the microcontroller to the website through the Arduino software's help, aiming to be the program's success before taking data. The testing phase of ardupilot by connecting to the ardupilot software installed on the laptop aims for 
the Robot Boat to move accordingly Route commands that are run on the ardupilot the function of ardupilot software is as automatic and manual drive systems on the Robot Boat.

In collecting data, the Robot Boat covers a distance of 14 meters with a time of 2 minutes 50 seconds and with data collection of 34 water $\mathrm{pH}$ data because the monitoring program on the robot boat is carried out every 5 seconds.

\section{CONCLUSION}

Water $\mathrm{pH}$ measurement can be done with a Robot Boat, which can read river water quality in real-time with the ESP8266 microcontroller. The time takes for Robot Boat to cover an area of $25.2 \mathrm{~m} 2$ is 1 minute. Seventeen data of water $\mathrm{pH}$ due to the monitoring program on the Robot Boat in real-time; every 5 seconds by showing the water quality of the Winongo River 12 December 2019, with the morning at $6 \mathrm{AM}, 12 \mathrm{AM}$, and $6 \mathrm{PM}$ is in the morning with a water $\mathrm{pH}$ value of 6.81 for a stormy / heavily polluted statement, during the day with a water $\mathrm{pH}$ value at 6.77 for a statement as bad / Severely Polluted. With the water $\mathrm{pH}$ value of 6.66 , the information is poor / heavily polluted in the afternoon.

\section{SUGGESTION}

The next development suggestion is that the battery capacity of the Robot Boat is still limited, the maximum distance of the Robot Boat with the system is 500 meters, and it needs additional methods. Thus, the Robot Boat can avoid objects in front of it. It is hoped that this Robot Boat can be implemented to help monitor river water quality for government agencies such as IPAL (wastewater treatment plants) and the Environmental Service.

\section{BIBLIOGRAPHY}

[1] Galih, S. dan Heru, D.W., 2015. Instalasi Sistem Pemantauan Kualitas Air Online Berbasis GSM di Sungai Ciliwung Segmen Istiqlal. Pusat Teknologi Lingkungan BPPT. JAI, 8(1).

[2] Kusuma, F.I., 2014. Karakteristik Kualitas Air Sungai Winongo Das Opak Setelah Melewati Kawasan Perkotaan Daerah Istimewa Yogyakarta Tahun 2012-2014 (Doctoral Dissertation, Universitas Gadjah Mada).

[3] Yogafanny, E., 2015. Pengaruh aktifitas warga di sempadan sungai terhadap kualitas air Sungai Winongo. Jurnal Sains dan Teknologi Lingkungan, 7(1), pp.29-40.

[4] Indrawati, S.I., 2012. Keragaman Pemanfaatan Sungai Oleh Masyarakat Pada Bantaran Sungai Winongo Di Kecamatan Ngampilan Dan Mantrijeron Kota Yogyakarta Tahun 2010 (Doctoral Dissertation, Universitas Muhammadiyah Surakarta).

[5] Verandika, H., 2018. Kampung Vertikal Di Ngampilan Bantaran Kali Winongo, Yogyakarta Dengan Sistem Pengolahan Sampah Mandiri Menggunakan Pendekatan Arsitektur Adaptif Lingkungan (Doctoral Dissertation, Universitas Gadjah Mada). 